Synthesis and Characterization of Cobalt Ferrite / Graphene for The Removal of Sulfur from Kerosene by Oxidative Desulfurization

Omar G. Hammoodi, Emaad T. Bakir Al-Tikrity and Karim H. Hassan

\title{
Synthesis and Characterization of Cobalt Ferrite / Graphene for The Removal of Sulfur from Kerosene by Oxidative Desulfurization
}

\author{
Omar G. Hammoodi ${ }^{* 1}$, Emaad T. Bakir Al-Tikrity ${ }^{1}$ and Karim H. Hassan ${ }^{2}$ \\ ${ }^{1}$ Department of Chemistry - College of Sciences - University of Tikrit - Tikrit - Iraq \\ ${ }^{2}$ Department of Chemistry - College of Sciences - University of Diyala - Baquba - Iraq \\ *Omarghazih@gmail.com
}

Received: 20 January $2019 \quad$ Accepted: 31 March 2019

\section{$\underline{\text { Abstract }}$}

In this study, a nanocomposite cobalt ferrite / graphene, CoFe2O4-G was prepared by sol-gel method, and was identified by (XRD, AFM, and SEM) techniques. The composite was used to remove sulfur from the Iraqi kerosene (Al-Doura refinery) with a concentration of $500 \mathrm{ppm}$ of sulfur. Oxidative desulfurization was used in the sulfur removal from kerosene and the composite appeared to have good effectiveness in the removal of sulfur from this kerosene under various conditions (Time, temperature, $\mathrm{O} / \mathrm{S}$ ratio, and catalyst weight) as it showed a high removal activity of sulfur at optimum conditions which exceed $90 \%$.

Keywords: Oxidative desulfurization, Kerosene, Cobalt ferrite, Sulfur removal.

$$
\begin{aligned}
& \text { تحضير وتثخيص متراكب الكوبلت فيرايت / الكرافين لازالة الكبريت من الكيروسين في عملية ازالة } \\
& \text { الكبريت بالاكسدة } \\
& \text { عمر غازي حمودي1 ، عماد طه بكر } 1 \text { و كريم هنيكش حسن2 }
\end{aligned}
$$

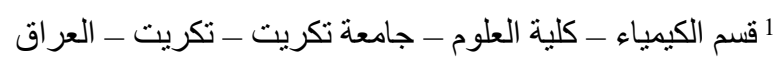

$$
\begin{aligned}
& \text { 2قسم الكيمياء جامعة ديالى - كلية العلوم - بعقوبة - العراق }
\end{aligned}
$$


Synthesis and Characterization of Cobalt Ferrite / Graphene for The Removal of Sulfur from Kerosene by Oxidative Desulfurization

Omar G. Hammoodi, Emaad T. Bakir Al-Tikrity and Karim H. Hassan

\begin{abstract}
الخلاصة
في هذه الدر اسة، تم تحضير الكوبلت فير ايت/ الكر افين بواسطة طريقة sol-gel، وتم تتخيص المركبات المحضرة بتقنيات مختلفة (XRD,AFM,SEM)، و استخدام المتر اكب المحضر للإز الة الكبريت من الكيروسين العر اقي الذي تم الحصول عليه من مصفى الدورة حيث اجريت از الة الكبريت بواسطة عملية الإز الة المؤكسدة من الكيروسين واظهر المركب فعالية

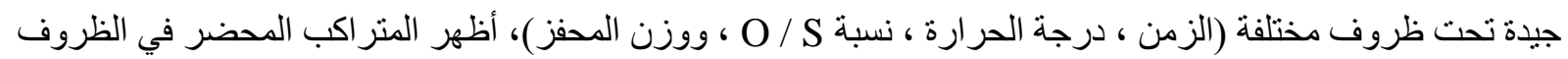
المثلى فعالية جيدة لسحب الكبريت تصل الى 90 \%. الكلمات المفتاحية: از الة الكبريت بالاكسدة، الكيروسين، كوبلت فير ايت، أزالة الكبريت.
\end{abstract}

\title{
$\underline{\text { Introduction }}$
}

The organosulfur / containing components in petroleum fuels output poisonous sulfur oxide gases through its oxidation, which can cause adverse effects on the environment [1]. Mercaptans as a type of sulfur materials is undesirable due to its unpleasant odours and corrosive properties [2]. Therefore, desulphurization of fuels is very important to environmental safety and has become a major challenge of the world [3]. The usual hydrodesulfurization (HDS) method displays high efficiency in the removal of sulfides, thiols, and mercaptans from fuels at industrial scale [4]. However, it is less effective in treating refractory alkylated organic sulfur compounds such as dibenzothiophene (DBT) and its derivatives due to the steric hindrance of these compounds [5,6]. Mentioned technology needs too high temperatures, high pressure, and high hydrogen exhaustion. Therefore, HDS is not appropriate for affordable reduction of the sulfur content from fuel [7,8]. It has economic damages due to requirement of severe operation conditions like high hydrogen pressure and high temperature to catalytically decompose the more refractory organo-sulphur compounds [9]. Moreover, high active HDS catalysts are being required by the industry [10]. Therefore, alternated operations are needed to achieve low cost targets and can be operated in moderate conditions. Among the alternate operations to the conventional hydrodesufurization, desufurization through adsorption [11], bio-desulfurization [12,13], ionic liquid extraction [14], electrochemical oxidation [15] and oxidative desulphurization [16]. One of these is the oxidative desulfurization (ODS) in which, the refractory organo-sulphur compounds such as dibenzothiophene (DBT) can be oxidized to 


\section{DIYALA JOURNAL FOR PURE SCIENCES}

\section{Synthesis and Characterization of Cobalt Ferrite / Graphene for The Removal of Sulfur from Kerosene by Oxidative Desulfurization}

\section{Omar G. Hammoodi, Emaad T. Bakir Al-Tikrity and Karim H. Hassan}

their corresponding sulfones or/and sulfoxides, and subsequently are removed by adsorption or/and extraction with polar solvents $[17,18]$. For ODS process, a suitable oxidant, an active catalyst, the efficiency of some organic and inorganic oxidants is required. The $\mathrm{H} 2 \mathrm{O} 2$ is the most widely used, because of its environmentally friendly properties [19-21].

In the present work, we selected $\mathrm{CoFe}_{2} \mathrm{O}_{4}$-Graphene to be active in removing sulfur compounds from kerosene in ODS processes. The catalytic activities were evaluated for oxidative removal of dibenzothiophene in kerosene using $\mathrm{H}_{2} \mathrm{O}_{2}$ as oxidant.

\section{Experimental}

\section{Material used}

Graphite Powder (99\% purity) was purchased from applechim company, potassium permanganate, sodium nitrate, sulfuric acid (98\%), hydrogen peroxide (30\%), hydrazine hydrate, cobalt nitrate hexahydrate, iron nitrate nonahydrate, dibezothiophene, kerosene, ethanol and distilled water, were analytical point and were used without any purification.

The kerosene used were obtained from Dora refinery in Baghdad with specifications given in table 1.

Table 1: Properties of used kerosene

\begin{tabular}{|c|c|}
\hline Test & Result \\
\hline Density 15 oC & $0.7906 \mathrm{~g} / \mathrm{cm} 3$ \\
\hline Flash point (Adel) oC & 47.4 \\
\hline Final Boiling point oC & 245 \\
\hline Doctor Test & Neg. \\
\hline Distilled 185 oC Vol \% & 25 \\
\hline Sulfur Content Wt. \% & 0.0020 \\
\hline Smoke point (mm) & 28 \\
\hline Aromatics Content Vol. \% & 13 \\
\hline Calorific Value Kcal/Kg (gross) & 11087 \\
\hline
\end{tabular}


Synthesis and Characterization of Cobalt Ferrite / Graphene for The Removal of Sulfur from Kerosene by Oxidative Desulfurization

Omar G. Hammoodi, Emaad T. Bakir Al-Tikrity and Karim H. Hassan

\section{Preparation of nanomaterials}

\section{Preparation of graphene oxide and Graphene}

Hummer method [22] was used to oxidize the graphite's for the preparation of GO and follows:

$2 \mathrm{gm}$ of graphite, $1.3 \mathrm{gm}$ of sodium nitrate (NaNO3) and $50 \mathrm{ml}$ of sulfuric acid (H2SO4) were placed in $500 \mathrm{ml}$ reaction flask and then immersed in ice bath. It is then mixed and stirred at $0^{\circ}$ $\mathrm{C}$ for 15 minutes. Then $6 \mathrm{gm}$ of potassium permanganate $(\mathrm{KMnO} 4)$ was added slowly to the above solution and cooled for 30 minutes. The suspended solution was stirred continuously for 1 hour at $35^{\circ} \mathrm{C}$, and $92 \mathrm{ml}$ water was added drop wise to the suspension for 10 minutes. The solution was left with stirring for $1 \mathrm{hr}$. Subsequently, the suspension was diluted by $280 \mathrm{ml}$ of warm water and stirred for 4 hours and maintained at room temperature, treated with $15 \mathrm{ml}$ (30\%) $\mathrm{H} 2 \mathrm{O} 2$ to reduce superfluity permanganate to soluble manganese ions. Finally, the resulting suspension was filtered, washed with distilled water, and dried in a vacuum oven at $70^{\circ} \mathrm{C}$ for 24 hours to obtain GO. Graphene was synthesized in a typical procedure as follows, GO $(100 \mathrm{mg})$ was loaded in a $250 \mathrm{ml}$ round bottomed flask and $(50 \mathrm{ml})$ water was then added, yielding a homogeneous yellow-brown dispersion solution. This was sonicated until it became clear with no visible particulate matter. Hydrazine hydrate $(1.00 \mathrm{ml})$ was then added and the solution heated in an oil bath at $100^{\circ} \mathrm{C}$ using a water-cooled condenser for $24 \mathrm{~h}$. The reduced black solid GO gradually precipitated out. This product was isolated by filtration, and then washed continuously five times with $100 \mathrm{ml}$ of distilled water and finally dried in an oven at $70^{\circ} \mathrm{C}$ for 24 hours.

\section{Preparation of cobalt ferrite and cobalt ferrite / Graphene}

For preparation of $\mathrm{CoFe} 2 \mathrm{O} 4$ nanoparticle compound, the sol-gel method was implemented in which (1:2) molar ratios of $\mathrm{Co}(\mathrm{NO} 3) 2.6 \mathrm{H} 2 \mathrm{O}$, and $\mathrm{Fe}(\mathrm{NO} 3) 3.9 \mathrm{H} 2 \mathrm{O}$ were used, a typical reaction of cobalt nitrate hexahydrate [Co(NO3)2.6H2O], $(1.164 \mathrm{~g}, 4 \mathrm{mmol})$ was dissolved in distilled water $(25 \mathrm{ml})$ and separately, ferric nitrate nonahydrate $\mathrm{Fe}(\mathrm{NO} 3) 3.9 \mathrm{H} 2 \mathrm{O}$ (3.232 $\mathrm{g}, 8 \mathrm{mmol})$ was dissolved in distilled water $(50 \mathrm{ml})$. The two solutions were mixed together and 


\section{DIYALA JOURNAL FOR PURE SCIENCES}

\section{Synthesis and Characterization of Cobalt Ferrite / Graphene for The Removal of Sulfur from Kerosene by Oxidative Desulfurization}

\section{Omar G. Hammoodi, Emaad T. Bakir Al-Tikrity and Karim H. Hassan}

added slowly to an aqueous solution of citric acid (2.304 g), then, ammonia solution (NH4OH) was added to the above solution to adjust the $\mathrm{pH}$ value to 7 , and stabilize the nitrate-citrate solution. During this process, the solution was continuously stirred using a magnetic stirrer with keeping the temperature at $50^{\circ} \mathrm{C}$, then the mixture was poured into beaker $(250 \mathrm{ml})$, and heated slowly to $90-95^{\circ} \mathrm{C}$ with stirring until it became viscous and the color changed and turned into a green porous dry gel. The dried gel was completely burn out to produce a loose powder and then submitted to calcinations at $600^{\circ} \mathrm{C}$ for 2 hours [23]. Finally, the $\mathrm{CoFe} 2 \mathrm{O} 4$ nanoparticles was obtained, as displayed in scheme 1 . To disperse $\mathrm{CoFe} 2 \mathrm{O} 4$ nanoparticles on $\mathrm{G}$, an amount of $\mathrm{CoFe} 2 \mathrm{O} 4$ and $\mathrm{G}$ were dispersed into absolute ethanol and ultrasonically treated for $10 \mathrm{~min}$. The gained mixture was dried at $60 \mathrm{oC}$ for $10 \mathrm{hr}$. in oven, and then ethanol was vaporized, leaving behind $\mathrm{CoFe} 2 \mathrm{O} 4$ nanoparticles well anchored on G. By changing the amount of $\mathrm{CoFe} 2 \mathrm{O} 4$, several samples with $\mathrm{G}$ content of $5 \%, 10 \%$ and $15 \%$ were prepared.

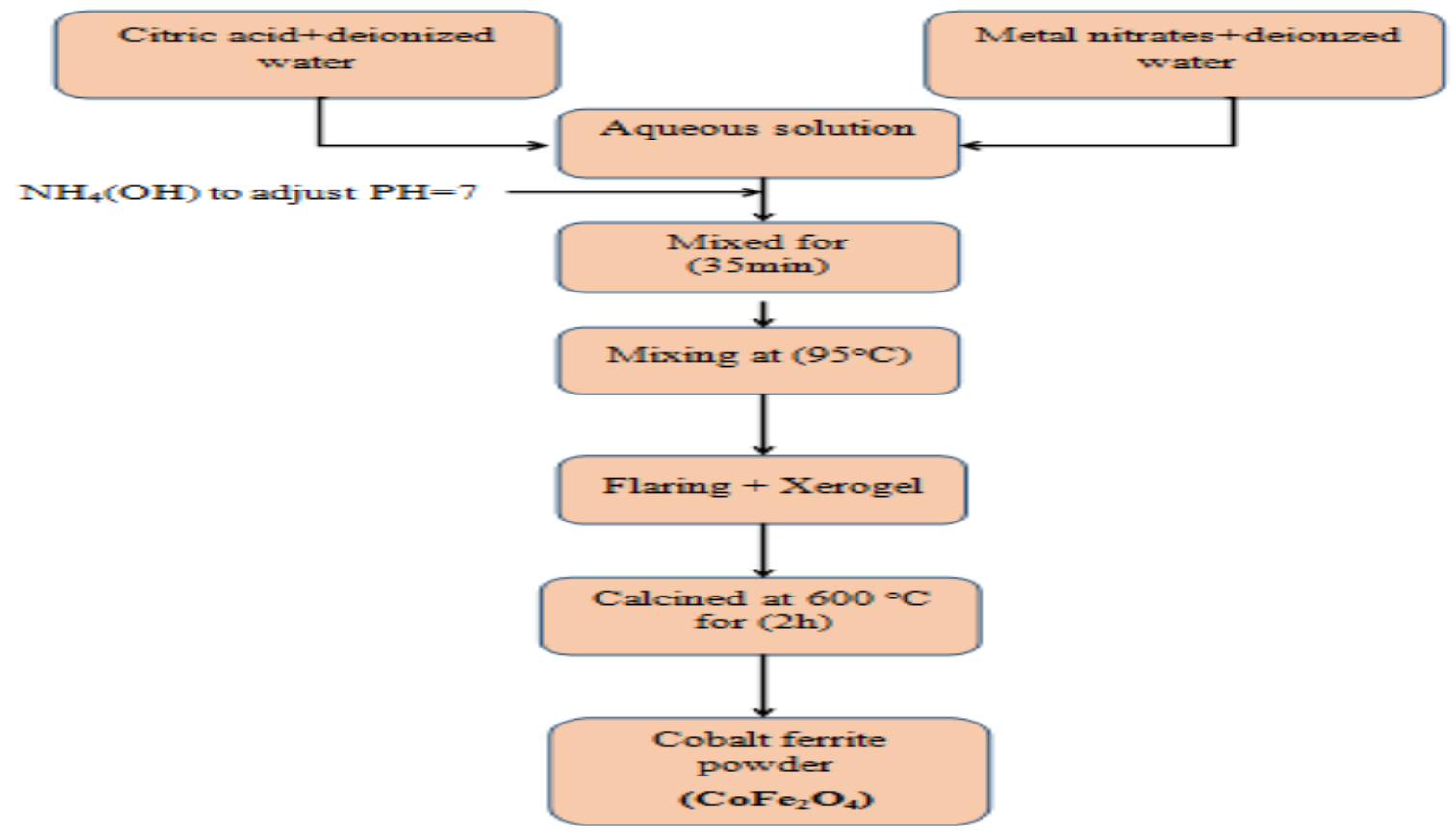

Scheme 1: The synthesis $\mathrm{CoFe}_{2} \mathrm{O}_{4}$ nanoparticles by sol-gel method 


\section{DIYALA JOURNAL FOR PURE SCIENCES}

Synthesis and Characterization of Cobalt Ferrite / Graphene for The Removal of Sulfur from Kerosene by Oxidative Desulfurization

Omar G. Hammoodi, Emaad T. Bakir Al-Tikrity and Karim H. Hassan

\section{Oxidative desulfurization process}

The kerosene sample with a sulfur concentration of $500 \mathrm{ppm}$ was prepared from hydrotreated kerosene which contain 20 ppm of sulfur and DBT by mixed the required amount, then the oil bath was first heated up and set at $60 \mathrm{oC} .20 \mathrm{~cm} 3$ of thus prepared kerosene, $\mathrm{H} 2 \mathrm{O} 2$ oxidant $(\mathrm{O} / \mathrm{S}$ $=5)$ and composite $(0.4 \mathrm{~g})$ were put into the round-bottom flask and refluxed at 1 atm pressure with strong stirring $(900 \mathrm{rpm})$ for 0.75 hour. After that, the oxidized kerosene was extracted by DMF, (DMF to Kerosene ratio of 1:6), followed by separation of kerosene from DMF in a separating funnel [24] and then the sulfur content of separated kerosene was measured by MultiTek instrument.

The percentage removal of sulfur compounds was calculated by applying the following equation:

$$
\text { Sulfur Removal } \%=\frac{\left(\mathrm{C}_{\mathrm{o}}-C_{t}\right)}{\mathrm{C}_{\mathrm{o}}} * 100
$$

Where Co is initial concentration of total sulfur in the Kerosene, $\mathrm{Ct}$ is total sulfur concentration in the treated Kerosene after reaction for $(\mathrm{t})$ minutes.

\section{$\underline{\text { Result and Discussion }}$}

\section{Characterization of nanocomposites:}

\section{X-ray Diffraction Characterization (XRD):}

The structure of the various modified samples is investigated by X-ray diffraction.

\section{X-ray diffraction of Graphene Oxide:}

Figure 1a explains the X-ray diffraction pattern (XRD) of GO powder. The disappearance of a sharp peak near $(2 \theta=26.49 \mathrm{o})(002)$ shows the changing in the crystalline structure of the graphite and indicated the destroying of the crystalline form of graphite. A large interlayer 
Synthesis and Characterization of Cobalt Ferrite / Graphene for The Removal of Sulfur from Kerosene by Oxidative Desulfurization

Omar G. Hammoodi, Emaad T. Bakir Al-Tikrity and Karim H. Hassan

spacing created equal to $8.803 \mathrm{~A}^{\circ}$ at the position $(2 \theta=10.0392 \mathrm{o})(001)$ and other two bands at $\left(2 \theta=25.9346^{\circ}\right)$ is attributed to the intermediate, beside the peak at $\left(2 \theta=54.3^{\circ}\right)$.

\subsubsection{X-ray Diffraction of graphene:}

From the XRD pattern of graphene, in figure (1b) one observed the major broad peak at about $(2 \theta=26.49 \mathrm{o})(002)$. This gives an interlayer spacing of approximately $3.54 \mathrm{~A}^{\circ}$. This interlayer spacing is much smaller than the $8.803 \mathrm{~A}^{\circ}$ for $\mathrm{GO}$, and is closer to the graphite peak. Moreover, it has a broad shoulder at approximately $\left(2 \theta=43^{\circ}\right)(100)$. The disappearing of the major strong peak at $(2 \theta=10.03920)$ in graphene indicated that the graphene oxide is converted to graphene.
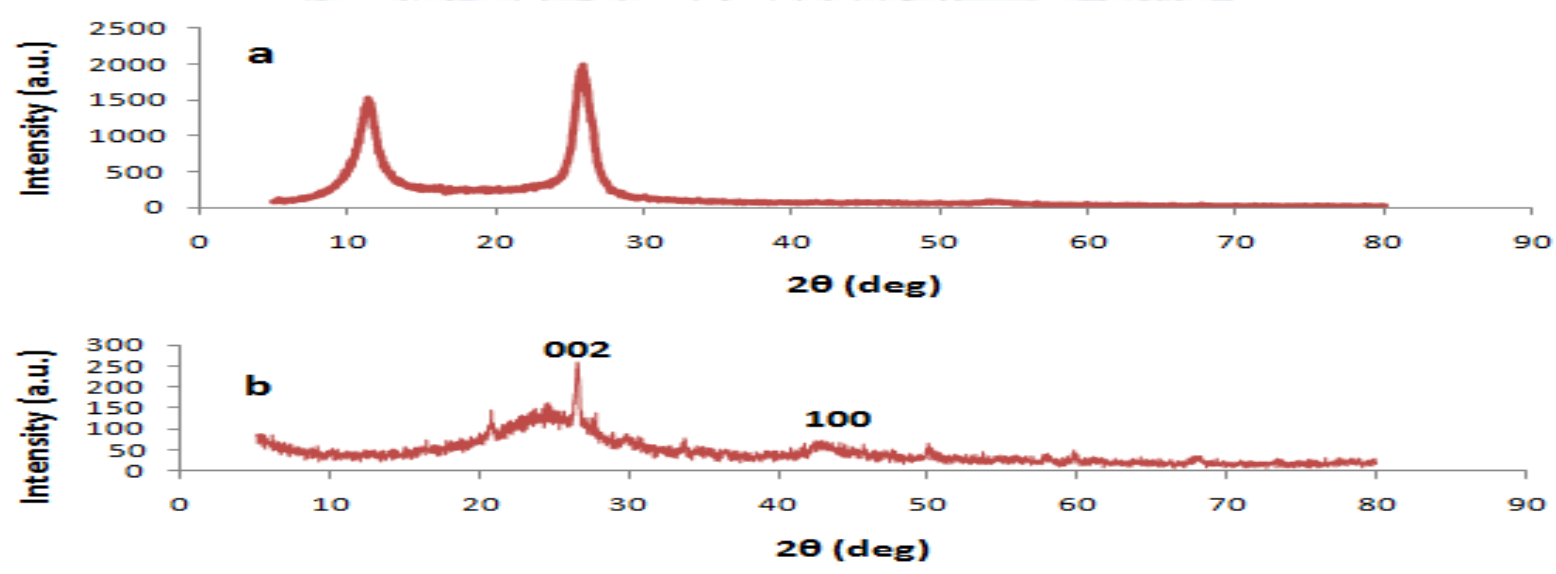

Figure 1: XRD of (a) GO, (b) G.

\section{X-ray Diffraction of cobalt ferrite}

The XRD structural properties of the synthesized CoFe2O4 pattern in figure (2a) shows the characteristic peaks of the following reflection planes (111), (220), (311), (400), (422), (511), (440), and (533). These planes prove the presence of a spinel cubic structure. The average crystalline size was studied using the Debye-Scherrer's formula, and was found to be 31.18 $\mathrm{nm}$. 
Synthesis and Characterization of Cobalt Ferrite / Graphene for The Removal of Sulfur from Kerosene by Oxidative Desulfurization

Omar G. Hammoodi, Emaad T. Bakir Al-Tikrity and Karim H. Hassan

\section{X-ray Diffraction of cobalt ferrite-graphene nanocomposite}

The phase structures of as-synthesized samples were firstly determined by XRD shown in Figure $2 b$. The XRD for CoFe2O4-G shows a sharp peak at $2 \theta$ of 26.580 corresponding to the (002) reflection of G. By contrast, the main diffraction peaks at $2 \theta=30.79 \mathrm{o}, 35.40 \mathrm{o}, 42.49 \mathrm{o}$, $56.91 \mathrm{o}$ and $62.52 \mathrm{o}$ are well matching with the spinel structure of cobalt ferrite (JCPDS card no.22-1086), which agree to crystal indexes of (220), (311), (400), (511) and (440), respectively [25].

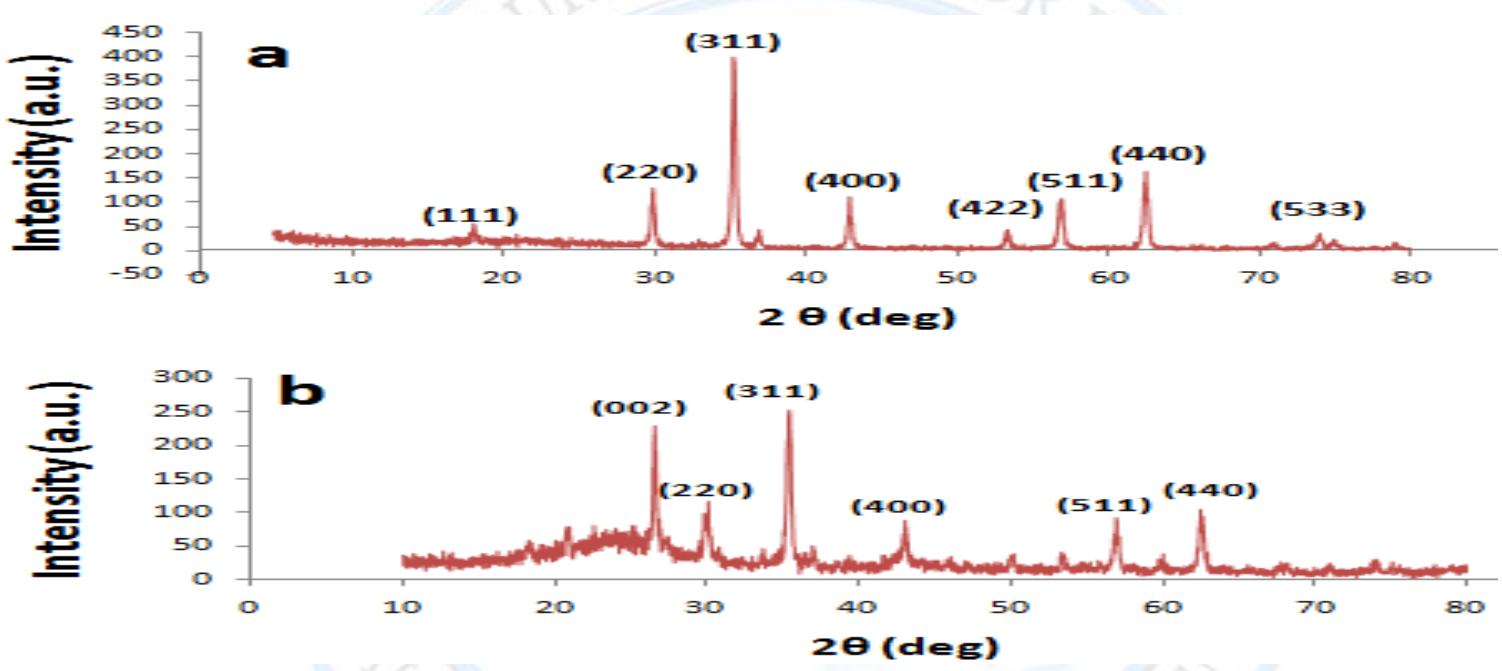

Figure 2: $\mathrm{XRD}$ of (a) $\mathrm{CoFe}_{2} \mathrm{O}_{4}$, and (b) $\mathrm{CoFe}_{2} \mathrm{O}_{4}-\mathrm{G}$

\section{AFM of characterization studies}

\section{AFM of graphene oxide}

The AFM image shown in figure 3a is for graphene oxide produced by Hydro thermal method. It was clear that this method produces GO sheets exfoliated from graphite, overlapping each other despite the separation between them. Measurements of AFM indicated that the highest thickness of the sheets was $21.03 \mathrm{~nm}$ in the three-dimensional form of the sample. The length of the sheet was $2361.55 \mathrm{~nm}$. The height of the sheet was $(13.10 \mathrm{~nm})$, such sheet thickness value was suggested to demonstrated presence of oxidized functional groups on edges of single GO sheets. So, the graphene oxide was synthesized in nano size. 


\section{DIYYALA JOURNAL FOR PURE SCIENCES}

Synthesis and Characterization of Cobalt Ferrite / Graphene for The Removal of Sulfur from Kerosene by Oxidative Desulfurization

Omar G. Hammoodi, Emaad T. Bakir Al-Tikrity and Karim H. Hassan

\section{AFM of graphene}

The AFM measurement showed that the graphene sheets is of thickness about $8.88 \mathrm{~nm}$, with the exception of the sheets which doped with $\mathrm{CoMoO} 4$, and the image measurement indicated that the graphene sheets was produced by reducing the functional groups on edges of single GO sheets. Figure $3 \mathrm{~b}$ illustrates it.
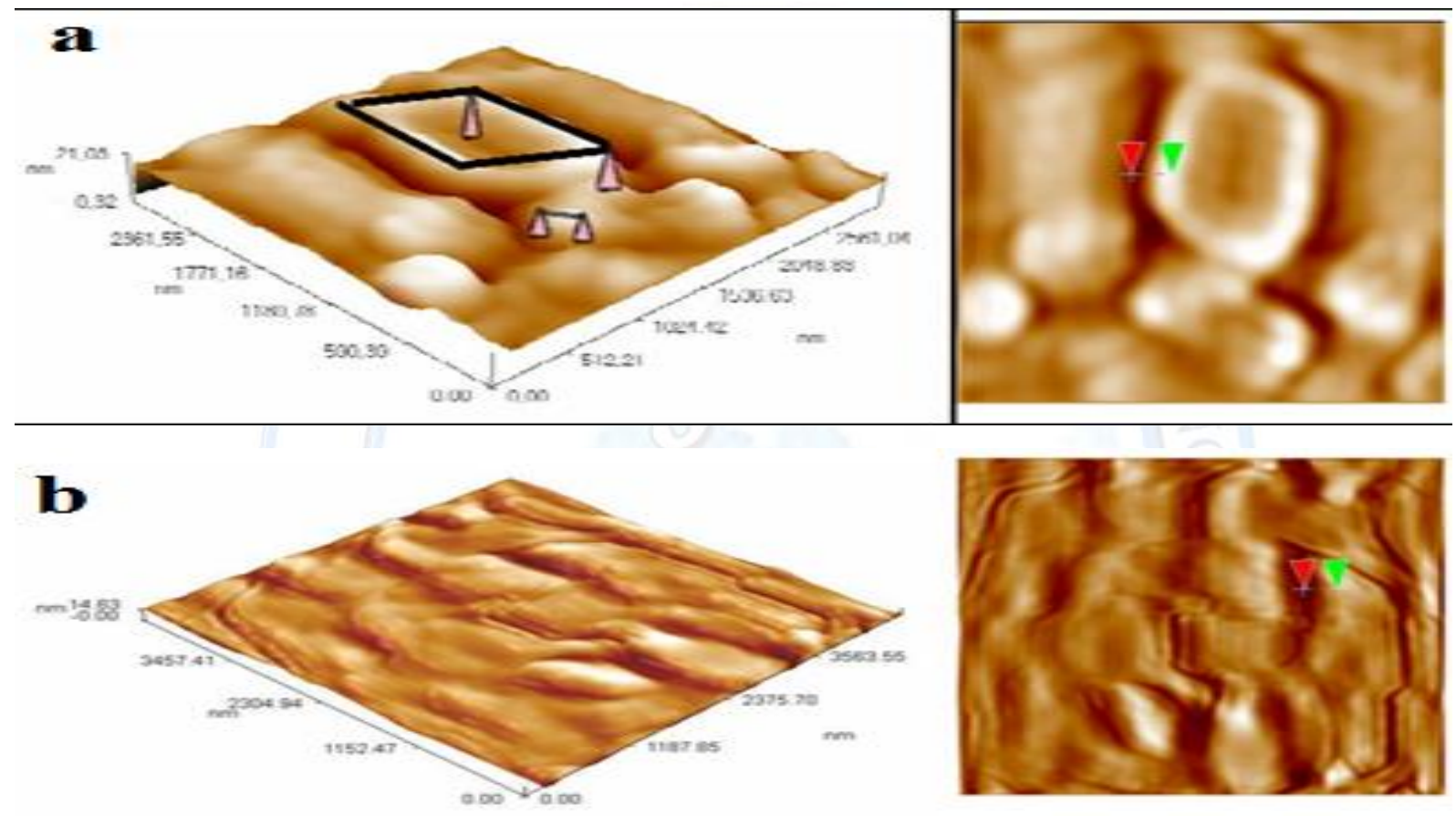

Figure 3: AFM images of (a) GO, (b) G

\section{AFM of Cobalt Ferrite}

Figure $4 \mathrm{a}$ is the AFM image of $\mathrm{CoFe} 2 \mathrm{O} 4$. it indicates that $10 \%$ of the prepared sample has $<65$ $\mathrm{nm}$ particle size and $50 \%$ has a particle size of $<85 \mathrm{~nm}$ and $90 \%$ has a particle size of $105 \mathrm{~nm}$ and the average particle size $85 \mathrm{~nm}$, and the height of detected place was $11.99 \mathrm{~nm}$.

\section{AFM of Cobalt Ferrite- graphene}

The AFM image shown in figure $4 \mathrm{~b}$ points to the thickness of $\mathrm{CoFe} 2 \mathrm{O} 4-\mathrm{G}$ sheets is about $5.75 \mathrm{~nm}$ and the height and length of it are $14.34 \mathrm{~nm}, 106 \mathrm{~nm}$ respectively. 


\section{DIYYALA JOURNAL FOR PURE SCIENCES}

Synthesis and Characterization of Cobalt Ferrite / Graphene for The Removal of Sulfur from Kerosene by Oxidative Desulfurization

Omar G. Hammoodi, Emaad T. Bakir Al-Tikrity and Karim H. Hassan

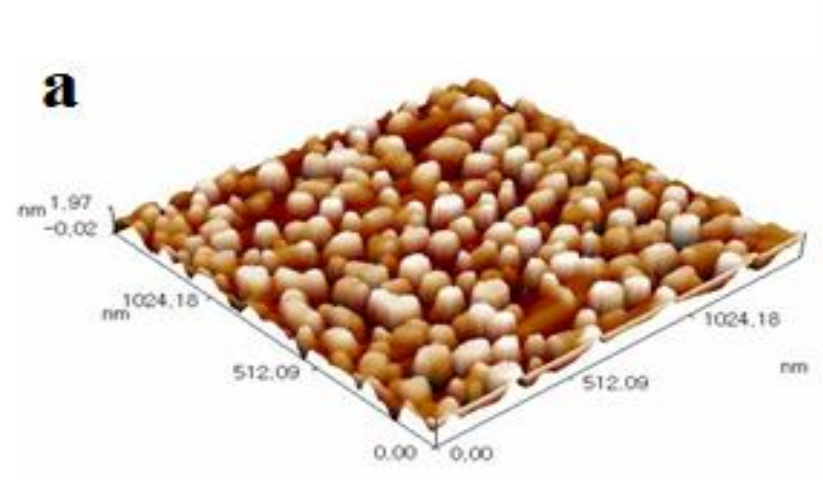

Avg. Diameter: $85.55 \mathrm{~nm}$

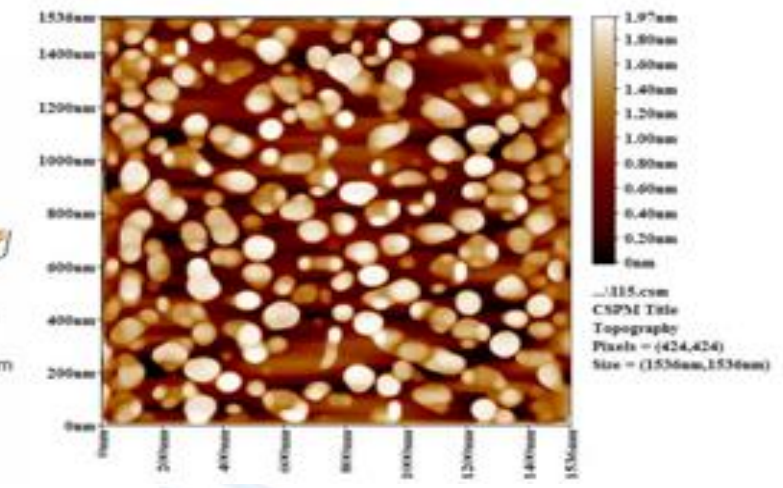

$<=50 \%$ Diameter: $85.00 \mathrm{~nm}$

$$
<=10 \% \text { Diameter: } 65.00 \mathrm{~nm}
$$
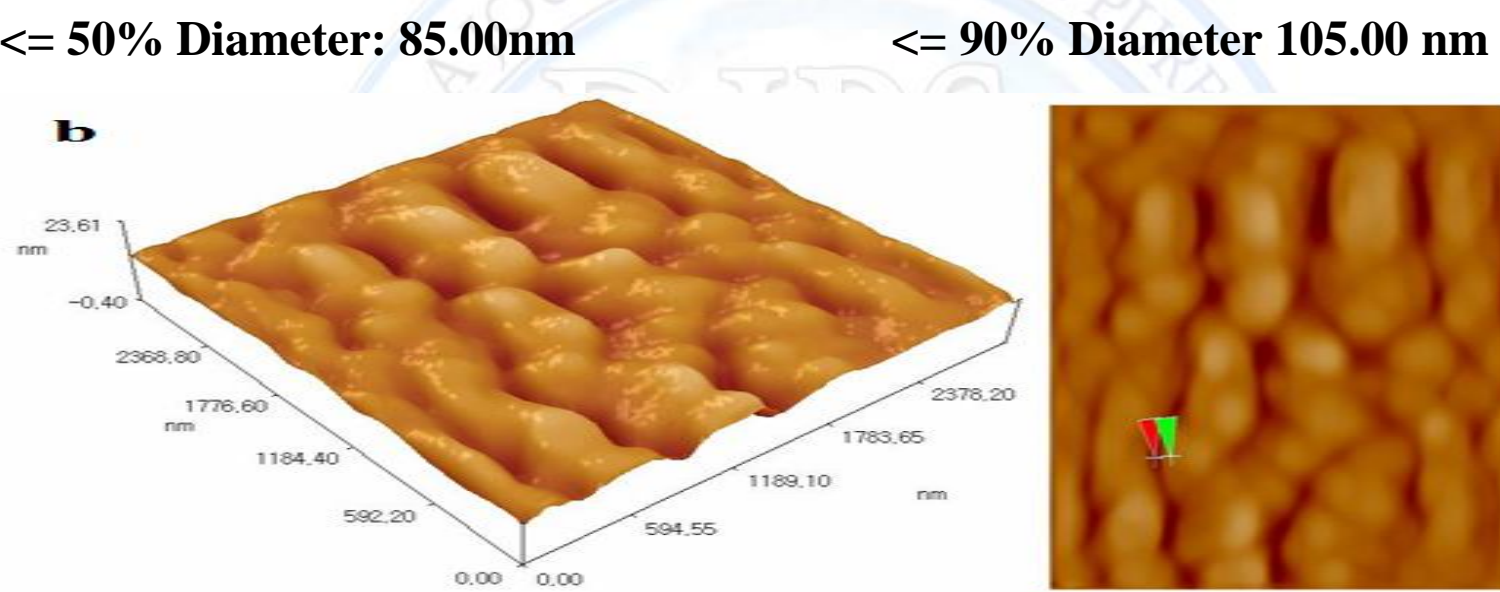

Figure 4: AFM images of (a) $\mathrm{CoFe}_{2} \mathrm{O}_{4}$, and (b) $\mathrm{CoFe}_{2} \mathrm{O}_{4}-\mathrm{G}$

\section{Scanning Electron Microscope}

\section{SEM of graphene}

The scanning electron microscopy (SEM) of the graphene showed that the $\mathrm{G}$ is in the form of sheets, but there are some abnormalities in this sheet due to the oxidation and reduction of the graphite and this is fully consistent with atomic force microscopy assays, seen in figure 5 (a1 and a2). 


\section{DIYYLA JOURNAL FOR PURE SCIENCES}

Synthesis and Characterization of Cobalt Ferrite / Graphene for The Removal of Sulfur from Kerosene by Oxidative Desulfurization

Omar G. Hammoodi, Emaad T. Bakir Al-Tikrity and Karim H. Hassan

\section{SEM of cobalt ferrite}

The scanning electron microscopy of cobalt ferrite $\mathrm{CoFe} 2 \mathrm{O} 4$ is shown in Figure 5 (b1 and b2) with magnification strength $500 \mathrm{~nm}$ and $1 \mu \mathrm{m}$. The prepared cobalt ferrite is in nanoparticle scale and this is in full consistent with atomic force microscopy data.

\section{SEM of cobalt ferrite- graphene}
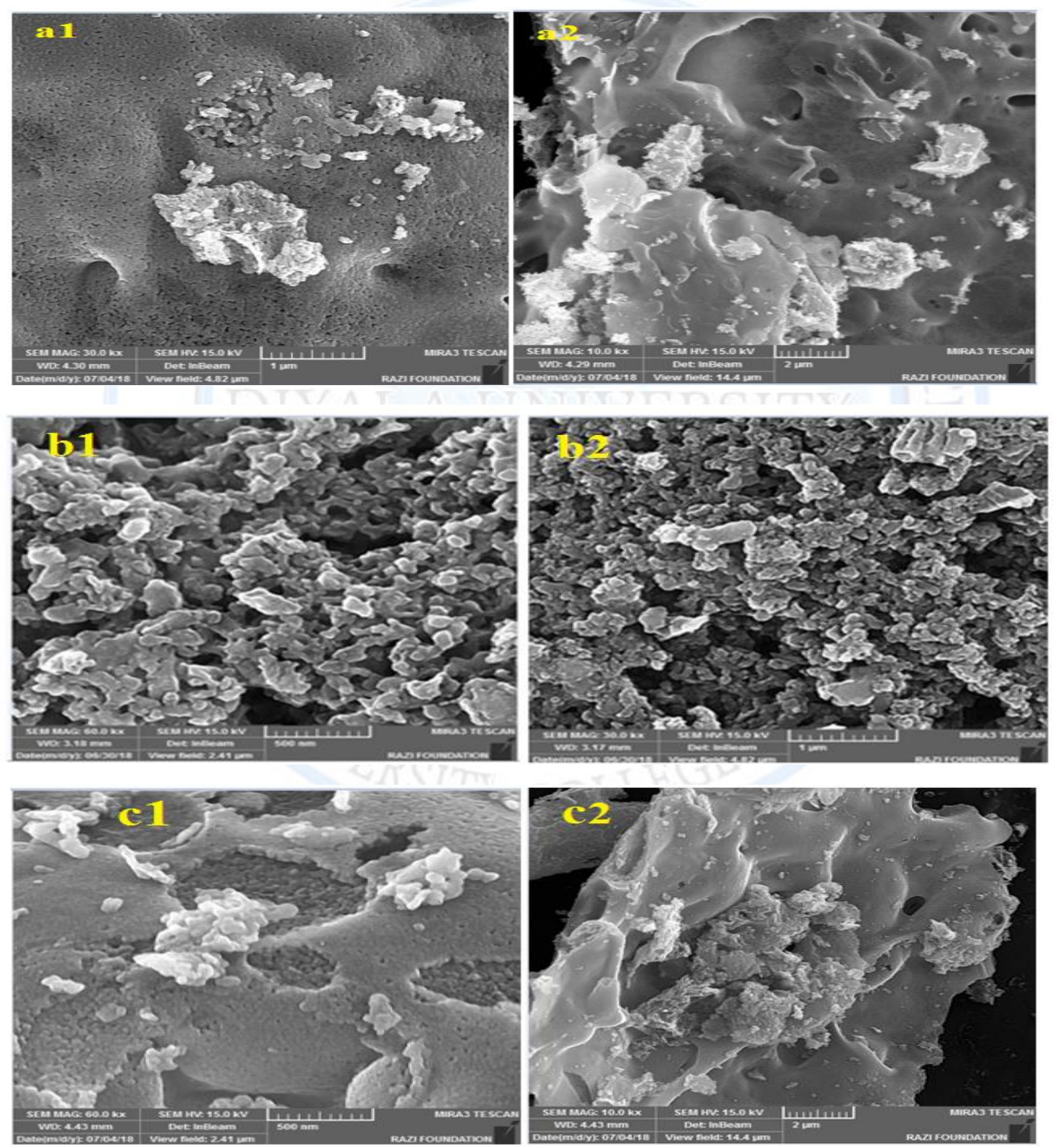

Figure 5: SEM of (a) $\mathrm{G}$, (b) $\mathrm{CoFe}_{2} \mathrm{O}_{4}$, and (c) $\mathrm{CoFe}_{2} \mathrm{O}_{4}-\mathrm{G}$ 


\section{DIYALA JOURNAL FOR PURE SCIENCES}

Synthesis and Characterization of Cobalt Ferrite / Graphene for The Removal of Sulfur from Kerosene by Oxidative Desulfurization

Omar G. Hammoodi, Emaad T. Bakir Al-Tikrity and Karim H. Hassan

The CoFe2O4-G nanocomposite in figure 5 (c1 and c2) explains the distribution of CoFe2O4 particles in between $\mathrm{G}$ sheets. In addition, the figure also depicts the aggregation of $\mathrm{CoFe} 2 \mathrm{O} 4$ particles because of the magnetic dipolar interaction between them.

\section{Oxidative desulfurization of kerosine}

The oxidative desulfurization was studied using different reaction conditions and as fallow:

\section{Effect of loading percentage}

Different loading percent of nanoparticles $(5 \%, 10 \%$ and $15 \%)$ were examined to limit the optimum quantity of catalyst for oxidation reaction and as in figure 6 . The sulfur removal efficiency seems to increase by raising the loading percent and reach the maximum percentage removal of $58 \%$ with the loading of the nanoparticle on the graphene sheet of $15 \%$.

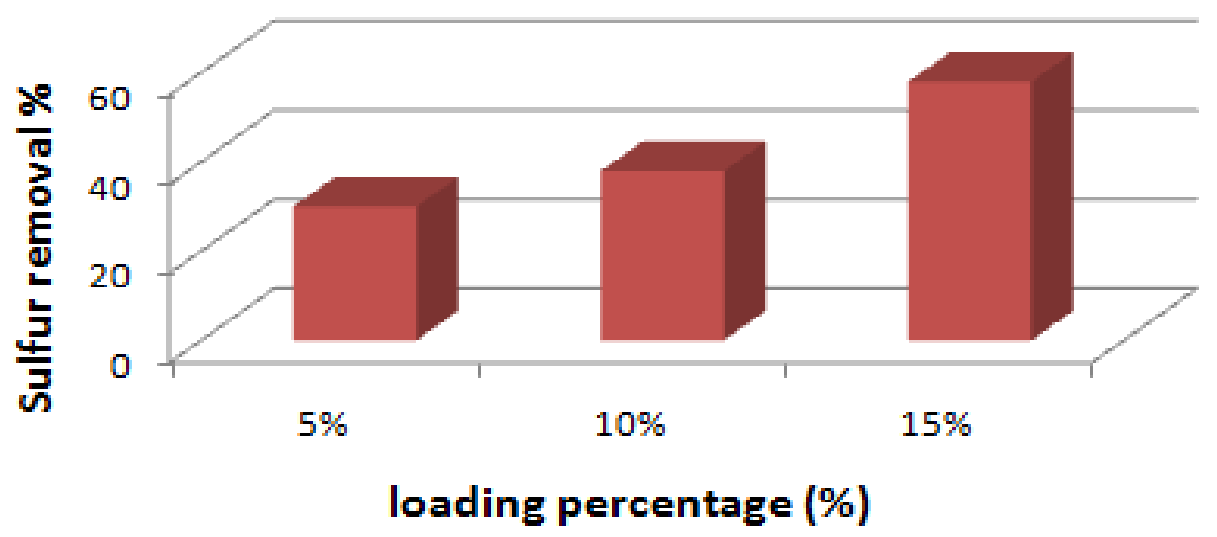

Figure 6: Effect of loading percentage on total sulfur removal \%

\section{Effect of reaction time}

In figure $7,0.25-2$ hours reaction times were examined for the catalytic sulfur removal efficiency. However, there is insignificant sulfur removal observed after 1-hour reaction time and for prolong reaction time of more than 1.5 hour, no much influence of time on the percentage of desulfurizations due to the degradation of most $\mathrm{H} 2 \mathrm{O} 2$ oxidant. 
Synthesis and Characterization of Cobalt Ferrite / Graphene for The Removal of Sulfur from Kerosene by Oxidative Desulfurization

Omar G. Hammoodi, Emaad T. Bakir Al-Tikrity and Karim H. Hassan

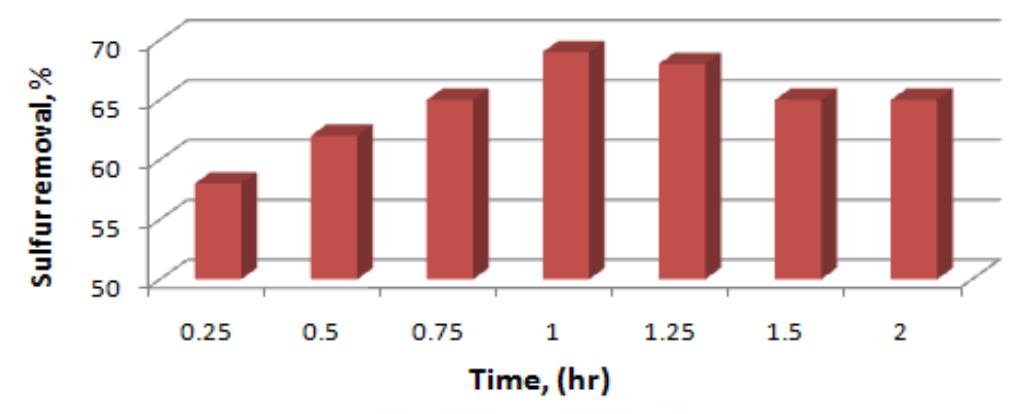

Figure 7: Effect of contact time on sulfur removal

\section{Effect of reaction temperature}

The effect of reaction temperature was studied with reaction conditions:

\section{Reaction conditions}

kerosene containing (DBT), $0.5 \mathrm{~g}, \mathrm{O} / \mathrm{S} 5 \mathrm{~mol}$ ratio, 0.75 hour and $900 \mathrm{rpm}$ at different temperature $\left(35,40,50,60,70\right.$ and $\left.80^{\circ} \mathrm{C}\right)$, and the results are shown in figure 8 . The increase of reaction temperature from 30 to $60^{\circ} \mathrm{C}$ will improve activity of sulfur from kerosene to a value of $75.3 \%$ at $60^{\circ} \mathrm{C}$. The highest selected temperature was $60^{\circ} \mathrm{C}$ because it had the highest removal of sulfur. On the other hand, higher temperature will initiate decomposition of $\mathrm{H} 2 \mathrm{O} 2$, and destroy the oxidation ability [26,27]. The reason is indicated that increasing of the temperatures lead to increase the internal energy between the reacted compounds and hence will promote the rapid molecular movement, which will cause more efficiency desulfurization.

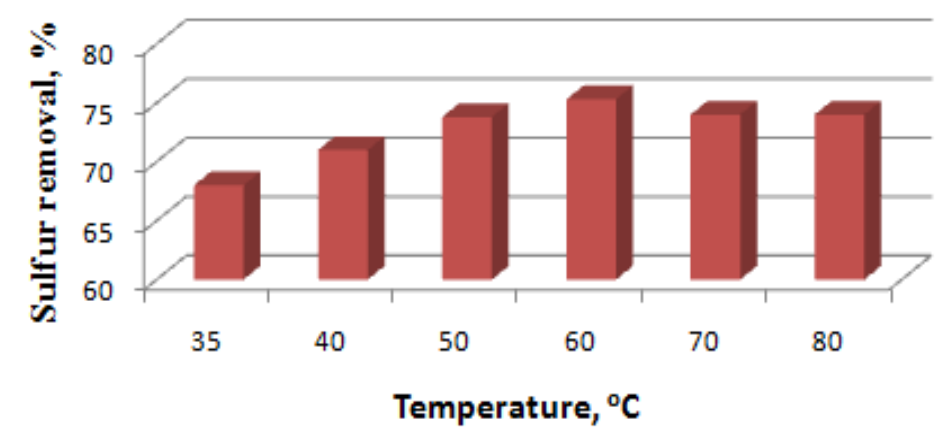

Figure 8: Effect of temperature on sulfur removal 


\section{DIYALA JOURNAL FOR PURE SCIENCES}

Synthesis and Characterization of Cobalt Ferrite / Graphene for The Removal of Sulfur from Kerosene by Oxidative Desulfurization

Omar G. Hammoodi, Emaad T. Bakir Al-Tikrity and Karim H. Hassan

\section{Effect of $\mathrm{O} / \mathrm{S}$ ratio}

The effect of the oxidizing agent $(\mathrm{H} 2 \mathrm{O} 2)$ to sulfur content ratio oxygen/sulfur $(\mathrm{O} / \mathrm{S})$ on the desulfurization efficiency is shown in figure 9. The results disply that the sulfur removal efficiency increases with increasing of oxygen/sulfur $(\mathrm{O} / \mathrm{S})$ ratio. When $\mathrm{O} / \mathrm{S}$ equal 5 molar ratios, which is higher than the reaction stoichiometry, the sulfur removal was $81.1 \%$. On the otherhand, when $\mathrm{O} / \mathrm{S}$ molar ratio increased more than 5, the oxidant content lead to decrease the sulfur removal efficiency, due to unproductive decomposition of $\mathrm{H} 2 \mathrm{O} 2$ to $\mathrm{O} 2$ and water which is then reduce the oxidation efficiency.

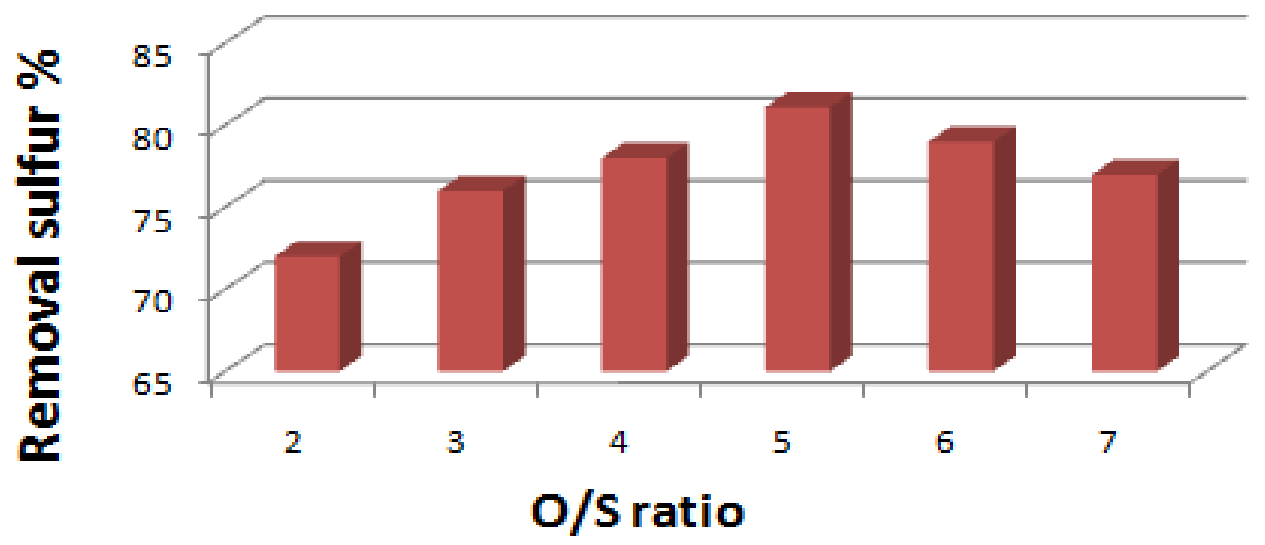

Figure 9: Effect of O/S molar ratio on sulfur removal

\section{Effect of catalyst quantity}

Different catalyst weight of $0.1,0.2,0.3,0.4,0.5$ and $0.6 \mathrm{~g}$ were examined to limit the optimum weight of catalyst required for oxidation reaction and as in Figure 10. The efficiency of sulfur removal is rose by increasing the catalyst mass and becoming maximum sulfur removal percentage of $90 \%$ when the weight of the catalyst is $0.5 \mathrm{~g}$. Extra increase in the catalyst weight caused a decrease of the sulfur removal efficiency; less than $86 \%$ sulfur removal at a catalyst weight of $0.6 \mathrm{~g}$. This decrease in efficiency could be referred to an agglomeration and aggregation effects, which minimized the number of active sites on catalyst surface which then reduce the effective surface area [27]. 
Synthesis and Characterization of Cobalt Ferrite / Graphene for The Removal of Sulfur from Kerosene by Oxidative Desulfurization

\section{Omar G. Hammoodi, Emaad T. Bakir Al-Tikrity and Karim H. Hassan}

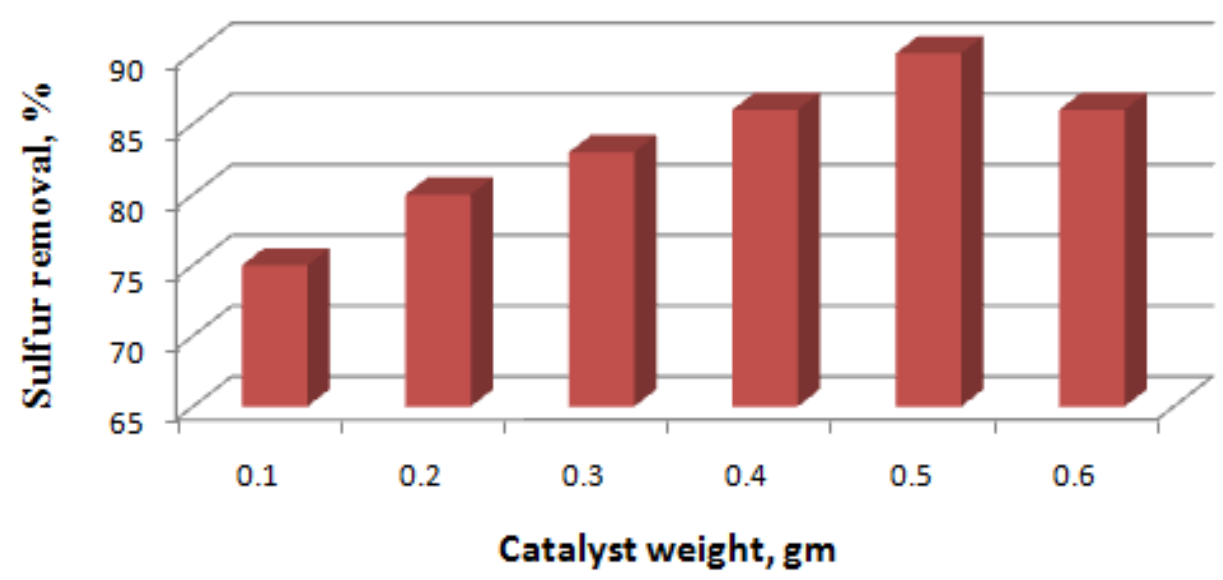

Figure 10: Effect of catalyst weight used on sulfur removal

\section{Conclusions}

CoFe2O4-G samples were selected for the study of the removal of sulfur by oxidative desulfurization from kerosene, where the results showed that the removal of sulfur the higher the loading rate (doping) of the reduced graphene oxides increased the rate of sulfur removal where the highest percentage of removal of sulfur is with loading rate of (15\%).

In addition, different conditions were experimented for the removal of sulfur reaction (time, temperature, $\mathrm{O} / \mathrm{S}$ ratio, catalytic weight), and the results exhibited that the increase in time and temperature increased the removal of sulfur. The results showed also that increasing the ratio of $\mathrm{O} / \mathrm{S}$ and the weight of the catalyst increases the rate the removal of sulfur and reaching a stable removal rate. 
Synthesis and Characterization of Cobalt Ferrite / Graphene for The Removal of Sulfur from Kerosene by Oxidative Desulfurization

Omar G. Hammoodi, Emaad T. Bakir Al-Tikrity and Karim H. Hassan

\section{$\underline{\text { References }}$}

1. L. Wanga, W. Wang, W. Mominou, L. Liub. S. Li, Appl. Catal. B 193, 180-188, (2016)

2. P. Kumara, K. Gillb, S. Kumar, K.G. Sudip, S. L. Jain, J. Mol. Catal. A: Chem. 401, 48-54 (2015)

3. K. S. Triantafyllidis, E.A. Deliyanni, Chem. Eng. J., 236, 406-414 (2014)

4. B. Jiang, H. Yang, L. Zhang, R. Zhang, Y. Sun, Y. Huang, Chem. Eng. J. 283, 89-96 (2016)

5. Y. Zhu, X. Li, M. Zhu, Catal. Commu. 85, 5-8 (2016)

6. W. Ding, W. Zhu, J. Xiong, L. Yang, A. Wei, M. Zhang, H. Li, Chem. Eng. J., 266, 213-221 (2015)

7. S. Mondal, Y. Hangun - Balkir, L. Alexandrova, D. Link, B. Howard, P. Zandhuis, A. Cugini, C.P. Horwitz, T. Collin, J. Catal. Today 116, 554-561(2006).

8. H. Lü, W. Ren, H. Liao, W. Chen, Y. Li, Z. Suo, Appl. Catal. B 1380139, 79- 83 (2013)

9. R.T. Yang, Adsorbents: Fundamentals and Applications, (Wiley, New York, 2003), pp. 345-346.

10. G. M. Dhar, G. M. Kumaran, M. Kumar, K. S. Rawat, L. D. Sharma, B. D. Raju, K. S. R. Rao, Catal. Today, 99, 309-314 (2005)

11. S. Dasgupta, V. Agnihotri, P. Gupta, A. Nanoti, M. O. Garg, A. N. Goswami, Catal. Today, 141, 84-88 (2009).

12. M. Ishaq, M. Shakirullah, I. Ahmad, M. Khan, Chem. Indian J. 2, 68-74 (2005)

13. I. B. W. Gunam, Y. Yaku, M. Hirano, K. Yamamura, F. Tomita, T. Sone, K. Asano, J. Biosci. Bioeng., 101, 322-327 (2006)

14. H. Li, L. He, J. Lu, W. Zhu, X. Jiang, Y. Wang, Y. Yan, Energy Fuels 23, 1354-1357 (2009)

15. W. Wang, S. Wang, H. Liu, Z. Wang, Fuel 86, 2747-2753 (2007)

16. W. Trakarnpruk, K. Rujiraworawut, Fuel Proc. Technol., 90, 411-414 (2009)

17. Y. Jia, G. Li, G. Ning, Fuel Process. Technol, 92, 106-111 (2011)

18. U. Arellano, J. M. Shen, J. A. Wang, M. T. Timko, L. F. Chen, J. T. Vázquez Rodríguez, M. Asomoza, A. Estrella, V.O.A. González, M.E. Llanos, Fuel 149, 15-25 (2015)

19. F. Al-Shahrani, T. Xiao, S.A. Llewellyn, S. Barri, Z. Jiang, H. Shi, G. Martinie, M.L.H. Green, Appl. Catal. B Environ. 73, 311-316 (2007)

20. G. A. Bagiyan, I. K. Koroleva, N.V. Soroka, A.V. Ufimtsev, Kinet. Catal. 45, 372-380 (2004)

21. S. Murata, K. Murata, K. Kidena, M. Nomura, Energy Fuel 18, 1, 116-121 (2004) 
Synthesis and Characterization of Cobalt Ferrite / Graphene for The Removal of Sulfur from Kerosene by Oxidative Desulfurization

\section{Omar G. Hammoodi, Emaad T. Bakir Al-Tikrity and Karim H. Hassan}

22. W. S. Hummers, R. E. Offeman, Preparation of graphitic oxide, J. Am. Chem. Soc. 80, 6, 1339 (1958)

23. A. Abdal - Wahhab, Preparation of nanocomposite conductive polymers used in the electrochemical cell, M.Sc. Thesis, University of Tiktit, salahddin, Iraq, (2016)

24. W. N. A. W. Mokhtar, W. A. W. A. Bakar, R. Ali, A. A. A. Kadir, Fuel 161, 26-33 (2015)

25. C. Wan, J. Li, Carbohydrate Polymers, 134, 144-150 (2015)

26. W. Abdul-Kadhim, M. A. Deraman, S. B. Abdullah, S. N. Tajuddin, M. M. Yusoff, Y. H. TaufiqYap, M. H. A. Rahim, Journal of Environmental Chemical Engineering 5,2, 1645-1656 (2017)

27. T. Parvin, N. Keerthiraj, I. A. Ibrahim, S. Phanichphant, K. Byrappa, International Journal of Photoenergy V2012, 1- 8 (2012) 